зі схожими проблемами, констатується низький рівень освіти та недостатня мотивація до подальшого навчання та власного професійного становлення, росту та активне включення в життя громади. Уцьому зв'язку визначено шляхи оптимізації системи соціального захисту осіб із інвалідністю в Україні, до яких віднесено підвищення державної матеріальної допомоги даній категорії населення, покращення медичного обслуговування, створення мережі центрів медико-соціальної реабілітації, надання необхідної освіти й працевлаштування та інше. Акцентовано на думці опитуваних про те, що саме узгоджена діяльність державних і місцевих органів влади щодо забезпечення чинного законодавства щодо реалізації прав $i$ можливостей молоді з інвалідністю в сучасному суспільстві сприятиме кращій інтеграції цієї категорії осіб.

Ключові слова: соціальна інтеграція, сочіальна мобільність, Україна, молоді люди з інвалідністю, молодь із особливими потребами.

\title{
PEЗЮME
}

Ионова Ирина, Кирилюк Анна, Косенко Юрий. Социальная интеграция молодых людей с инвалидностью в образовательное пространство и общественную жизнь Украины: состояние, проблемы и перспективы.

В статье освещена проблема интегрированности молодых людей с особыми потребностями в жизнедеятельность украинского общества (на примере Сумской области). Изложены результаты анкетирования лиц $c$ инвалидностью для выяснения осведомленности в отношении национального законодательства по защите прав лиц с инвалидностью, возможностей физического доступа к объектам социальной инфраструктуры. Определены пути оптимизации системы социальной защиты лиц с инвалидностью в Украине, к которым отнесены повышение государственной материальной помощи, улучшение медицинского обслуживания, создание сети центров медико-социальной реабилитации, предоставление необходимого образования и трудоустройства.

Ключевые слова: социальная интеграция, социальная мобильность, Украина, молодые люди с инвалидностью, молодежь с особыми потребностями.

удк 376.3:616.89-008.434.3

Галина Станецька

Національний педагогічний університет імені М. П. Драгоманова

ORCID ID 0000-0003-1623-6459

DOI 10.24139/2312-5993/2019.07/014-026

\section{ЛОГОПЕДИЧНЕ ДОСЛІДЖЕННЯ ПОРУШЕННЯ МОВЛЕННЯ ПРИ ПРОГРЕСУЮЧОМУ НАД'ЯДЕРНОМУ ПАРАЛІЧІ}

Описано особливості порушення мовлення в дорослих пацієнтів із прогресуючим над’ядерним паралічем. У логопедичному дослідженні взяли участь 5 пацієнтів. Ступінь порушення артикуляції, дихання, фонації, резонансу, просодії $i$ темпу мовлення оцінювали за 25 критеріями. Нейропсихологічні дослідження виявили помірні когнітивні порушення за шкалою M M SE (25-26 балів). Ідентифікована ступінь порушення кожного мовленнєвого кластера. Установлено, що в пацієнтів 
максимально порушені всі функції язика і гортані. Описано основні характеристики мовлення і зразки голосу. Перцептивне дослідження показало, що в усіх пацієнтів при прогресуючому над’ядерному паралічі на ранній стадії захворювання присутня дизартрія змішаного типу: гіпокінетична зі спастичним компонентом або гіпокінетична зі спастичним та атактичним компонентами.

Ключові слова: порушення мовлення, прогресуючий над’ядерний параліч, дизартрія.

Постановка проблеми. У зв'язку з покращенням умов життя в цілому світі спостерігається стійка тенденція до появи досить великої кількості осіб похилого віку, яким далеко за 60 років. Однак, не всі ці люди зберігають хороші фізичні і психологічні дані. У них починають проявлятися різні хвороби, які пов'язані з погіршенням пам'яті, уваги, фізичного стану, мовлення тощо. До них можна віднести хворобу Альцгеймера, хворобу Паркінсона та симптоматичні форми паркінсонізму, зокрема, прогресуючий над'ядерний параліч та хворобу Вільсона.

В основі всіх цих захворювань лежить дегенерація, зумовлена ураженням головного мозку, яка характеризуються порушеннями у мнестичних та інших когнітивних сферах, включаючи мовлення, просторову орієнтацію, абстрактне мислення та призводить до ускладнень у повсякденному житті або професійній діяльності (Оржешковський, 2011; Матвієнко, 2009). У випадках, коли мовлення пацієнта настільки уражене, що в повсякденному житті неможливо порозумітися з оточуючими, пацієнти звертаються до логопеда з надією, що зможуть хоч якось спілкуватися, що логопед їх зрозуміє й допоможе. Тоді перед логопедом постає завдання вирішення проблеми комунікації і в кожному окремому випадку це має бути індивідуальний підхід.

Аналіз актуальних досліджень. Прогресуючий над'ядерний параліч (ПНП) - це нейродегенеративне захворювання, викликане ураженням підкіркових і стовбурових структур, яке проявляється постуральною нестійкістю, що призводить до численних падінь, над'ядерним офтальмопарезом, псевдобульбарним синдромом (дизартрія, дисфонія, дисфагія) та деменцією підкірково-лобного типу (Дамулин, 2005; Ролак, 2018).

Прогресуючий над'ядерний параліч часто означують як атиповий паркінсонізм, який розвивається в 1 випадку на 10 випадків хвороби Паркінсона, а річна частота коливається в межах 0,3-1,1 випадків на 100 тис. населення. ПНП відомий ще як синдром Стіла-Річардсона-Ольшевського і найчастіше розвивається в дорослих осіб після 45 років (Матвієнко, 2009; Яхно, 2011).

ПНП уперше описаний у 1963-1964 роках неврологами J. Steele та J. Richardson спільно з патоморфологом J. Olszewski у серії статей, у яких був детально проведений клініко-патоморфологічний аналіз семи випадків невідомого раніше нейродегенеративного захворювання (Richardson, 1963; Steele, 1964). 
Випадки ПНП описувалися в науковій літературі і раніше, але помилково були інтерпретовані як прояви постенцефалітичного паркінсонізму, з яким ПНП має і клінічну, і патоморфологічну подібність (Шток, 2002; Яхно, 2011).

ПнП $\epsilon$ нейродегенеративним захворюванням, викликаним акумуляцією гіперфосфорильованого тау-протеїну в нейронах і гліальних клітинах. Цей білок нагромаджується у вигляді патологічних нейрофібрилярних клубків і нейропильних волокон.

Характерна клінічна картина ПНП визначається унікальним топічним розподілом дегенеративного ураження головного мозку. Для ПнП характерна мультифокальність процесу: у класичному дослідженні (Steele, 1964) було згадано про сорок уражених ядер. Не в кожному випадку спостерігається ураження всіх ядер, але в основному локалізація дегенеративного процесу $є$ досить стереотипною. Найчастіше ураженими $\epsilon$ чорна субстанція, бліда куля, субталамічне ядро, дорсальні відділи середнього мозку. Результатом цього процесу $€$ дезорганізація кірковостріато-палідо-таламо-фронтальних кіл, які регулюють різні аспекти моторних, когнітивних та поведінкових функцій.

Зазвичай, первинними ознаками захворювання $\epsilon$ постуральна нестійкість із частими падіннями (60\% випадків), дизартрія (33\%), сповільненість рухів (13\%) і розлади зору (13\%). Значно рідше первинними ознаками ПнП $є$ дисфагія та застигання при ходьбі. Це захворювання проявляється парезом вертикального погляду, акінетикоригідним синдромом, розвитком постуральної нестійкості з частим падінням назад, псевдобульбарним синдромом і деменцією лобного типу (Litvan, 1996; Ульянова, 2013; Lees, 1987).

У хворих на ПНП розвивається гіпомімія, яка робить обличчя «маскоподібним». Через спастичне напруження мімічних м'язів риси обличчя не згладжуються, як часто буває при хворобі Паркінсона, а загострюються. При цьому обличчя набуває характерного виразу, який можна описати як «здивування». Проявляються рухові і мовленнєві персеверації, палілалія, ехопраксія, ехолалія (Collins, 1995; Kluin, 1993; M etter, 1991).

При ПнП на ранніх стадіях розвиваються тяжкі псевдобульбарні прояви - дизартрія, дисфагія, рефлекси орального автоматизму. Дизартрія, дуже часто змішаного типу з гіпокінетичним, спастичним і атактичним компонентом, розвивається вже на першому році захворювання й випереджає розлади зору на 1-2 роки. Через 2 роки після початку захворювання тяжка дизартрія спостерігається у $40 \%$, а через 5 років у 68 \% хворих (Golbe, 1988; Lu, 1992; Станецька, 2016).

Порушення ковтання при ПнП проявляється через 3-4 роки після початку захворювання і найчастіше через 1-2 роки після розвитку дизартрії. Приблизно у $20 \%$ хворих чіткі клінічні прояви дисфагії виникають вже 
через 2 роки (Шток, 2002; Яхно, 2011). В основі дисфагії лежать гіпокінезія та ригідність орофарингеальних м'язів. При обстеженні орофарингеальна гіпокінезія проявляється при перевірці рухів язика зі сторони в сторону або при артикуляції губних звуків. У хворих часто спостерігається слинотеча (сіалорея), обумовлена сповільненим утрудненим ковтанням. При цьому атрофія і фасцикуляції язика відсутні. Як і при інших варіантах нейрогенної дисфагії вживання як рідкої, так і твердої їжі є утрудненим.

у статті (Федотова, 2009, с. 38) детально описано результати обстеження й лікування 70-річного хворого, у якого спостерігалися прояви псевдобульбарного синдрому (дизартрія, дисфагія, дисфонія). У хворого було порушене мовлення у вигляді зниження мовленнєвої активності, утруднення ініціації і розуміння мови. Когнітивні та емоційні розлади були помірними (Lebrun, 1986; Kluin, 2001).

Схожі спостереження описано (Оржешковський, 2011; Матвієнко, 2009). Автори сходяться на думці, що основними ознаками хвороби є: порушення ходи, рівноваги, падіння назад, похитування при ходьбі, скованість тіла, сповільненість рухів, порушення моторики очей разом із розладами мовлення, ковтання і когнітивними порушеннями.

На ранній стадії когнітивні розлади при ПНП характеризуються сповільненням психічної діяльності (брадифренія), швидким виснаженням і пригніченим настроєм. Брадифренія, особливо в сукупності зі зміною особистості, порушенням фіксації погляду, дизартрією та гіпомімією, може створити помилкове враження деменції, хоча інтелект у перші роки захворювання залишається, як правило, збереженим (Pillon, 1994; Яхно, 2011).

Труднощі, які зустрічаються при діагностиці ПнП, описано в статті (Ситкали, 2015, с. 273). У цій публікації детально описано результати обстеження і лікування 54-річної пацієнтки. У неї спостерігалися сповільненість рухів голови і тулуба, гіпомімія, маскоподібність обличчя, ригідність м'язів шиї та спини, тремор спокою, тремор рук, окорухові порушення, вегетативна недостатність (гіперсалівація, нетримання сечі). Основні симптоми, характерні для ПНП, автори порівнюють із симптомами хвороби Паркінсона. Відмічено, що у хворих із ПнП розвиваються тяжкі псевдобульбарні прояви - дизартрія і дисфагія, але, на відміну від хвороби Паркінсона, при ПНП спостерігається насильницький сміх і плач. У пацієнтів порушуються когнітивні та емоційні функції, які відображають функцію лобних часток головного мозку. Нейропсихологічні дослідження виявили помірні когнітивні порушення (тест М M SE - 25 балів).

Критичний аналіз наукових публікацій дозволяє стверджувати, що більшість із них присвячена висвітленню результатів медикаментозного лікування пацієнтів із прогресуючим над'ядерним паралічом, а дані про порушення мовленнєвих, рухових, когнітивних, емоційних, артикуляційних та голосових функцій залишаються поза увагою. Хоча саме ці проблеми створю- 
ють значні незручності пацієнтам, позбавляють їх можливості повноцінно жити, вільно спілкуватися, працювати та не бути залежними від сторонньої допомоги. Ці люди мають право на щасливе й комфортне життя. При неможливості вирішення перелічених проблем шляхом медикаментозного лікування на перший план виходить комплексна реабілітація. Стратегія комплексної нейрореабілітації, яка базується на мультидисциплінарному підході, повинна бути спрямована на позитивні зміни стану хворих і їх щоденне функціонування, покращувати мовлення, підвищувати гучність голосу, здатність до спілкування та інші комунікативні властивості (Станецька, 2018; Шмидт, 2019; Дунас, 2008; Федоришин, 2010; Смоленцева, 2019).

Перед логопедами постає важливе завдання: дослідити характер і ступінь порушення мовлення в дорослих із різними патологіями, вивчити причини, які призводять до цих порушень та розробити методики комплексної реабілітації з метою покращення мовлення, фізичного й морального стану дорослих. Високоефективне надання реабілітаційних послуг, основаних на взаємозв'язку між медичними, логопедичними, психологічними та педагогічними заходами, відновлення мовлення i спілкування дозволить молоді та дорослим із обмеженими можливостями швидше інтегруватися в суспільство .

I якщо проблеми порушення мовлення та інших функцій у дітей i молоді інтенсивно досліджуються логопедичною наукою, то ці самі проблеми, які виникають у дорослих, дуже мало вивчаються та описуються сучасними вченими. Зовсім відсутні дані щодо реабілітації мовлення в дорослих із ПНП.

Мета статті. Предметом даної публікації є логопедичне дослідження порушення мовлення в пацієнтів із прогресуючим над'ядерним паралічем з метою виявлення найбільш порушених функцій та вивчення можливості їх реабілітації.

Методи дослідження. У Львівській обласній клінічній лікарні в центрі екстрапірамідних захворювань нервової системи проведено обстеження розладів мовлення в 5 пацієнтів (2 чоловіків і 3 жінок) із ПнП, які на момент обстеження мали, відповідно, 48, 52, 60, 68 і 72 роки.

3 метою визначення ступеня порушення мовленнєвих функцій у пацієнтів проведено перцептивне обстеження артикуляції, дихання, фонації (голосу), резонансу, просодії і темпу мовлення за методикою дослідження дизартрії при екстрапірамідних розладах у дорослих (Станецька, 2018, с. 94).

Когнітивні функції диференціювали за короткою шкалою оцінки психічного статусу пацієнтів M ini-M ental State Exam (M M SE) (Folstein, 1975, с. 198).

Виклад основного матеріалу. Обстеження пацієнтів із ПНП дозволило встановити ступінь ураження кожного мовленнєвого параметра та виявити найбільш порушені функції. 
Сумарні результати індивідуального обстеження пацієнтів за порушеннями окремих функцій подано в таблиці 1.

У всіх пацієнтів найбільше порушені функції гортані (висота звуку, сила голосу, у мовленні), всі функції язика, губ (альтернативні рухи), дихання (в мовленні) та рефлекси (кашель). Незначно уражені функції м'якого піднебіння і щелепи (в стані спокою). Середній ступінь ураження мають функції дихання та губ (у стані спокою).

Таблиця 1

Сумарні результати індивідуального обстеження мовленнєвих функцій пацієнтів із ПНП

\begin{tabular}{|c|c|c|c|}
\hline \multirow{2}{*}{$\begin{array}{c}\text { Досліджувана } \\
\text { функція }\end{array}$} & \multirow[t]{2}{*}{ Назва, № } & \multicolumn{2}{|c|}{$\begin{array}{c}\text { Кількість пацієнтів, які } \\
\text { мали відхилення }\end{array}$} \\
\hline & & Ociб & Відсоток (\%) \\
\hline \multirow[t]{3}{*}{ 1. Рефлекси } & 1: кашель & 5 & 100 \\
\hline & 2: ковтання & 4 & 80 \\
\hline & 3: слиновиділення/слинотеча & 5 & 100 \\
\hline \multirow[t]{2}{*}{ 2 Дихання } & 4: у стані спокою & 3 & 60 \\
\hline & 5: у мовленні & 5 & 100 \\
\hline \multirow[t]{5}{*}{ 3. Губи } & 6: у стані спокою & 3 & 60 \\
\hline & 7: розтягнення & 4 & 80 \\
\hline & 8: змикання & 4 & 80 \\
\hline & 9: альтернативні рухи & 5 & 100 \\
\hline & 10: у мовленні & 4 & 80 \\
\hline \multirow[t]{2}{*}{ 4. Щелепа } & 11: у стані спокою & 2 & 40 \\
\hline & 12: у мовленні & 5 & 100 \\
\hline \multirow[t]{3}{*}{ 5. М’яке піднебіння } & 13: назальна регургітація & 1 & 20 \\
\hline & 14: підняття & 4 & 80 \\
\hline & 15: у мовленні & 4 & 80 \\
\hline \multirow[t]{4}{*}{ 6. Гортань } & 16: час фонації & 4 & 80 \\
\hline & 17: висота звуку & 5 & 100 \\
\hline & 18: сила голосу & 5 & 100 \\
\hline & 19: у мовленні & 5 & 100 \\
\hline \multirow[t]{6}{*}{ 7. Язик } & 20: у стані в спокою & 5 & 100 \\
\hline & 21: висування & 5 & 100 \\
\hline & 22: підняття & 5 & 100 \\
\hline & 23: бокові рухи & 5 & 100 \\
\hline & 24: альтернативні рухи & 5 & 100 \\
\hline & 25: у мовленні & 5 & 100 \\
\hline
\end{tabular}

Зразки мовлення всіх обстежуваних пацієнтів оцінювалися перцептивно. При цьому визначали моногучність, подовжені голосні, слабкий голос, монотонність, темп мовлення, затримку ініціації мовлення, наявність палілалії. Оцінювали зразки голосу: гіпокінетичний, стиснений/дистонічний, подовжений, атактичний. За голосовим зразком визначали вид мовлення. На основі одержаних даних зроблено такі висновки. 
Мова. При ПнП мовлення Є моногучним, тихим, монотонним, спостерігається нечітка артикуляція, сповільнене мовлення з напруженим стисненим голосом та легка гіперназальність. Спостерігаються труднощі при спробі посилити голос.

Голос. Порушення висоти звуку та сили голосу, що вказує на зміни функції гортані. Голос є слабким, хриплим, змінений тембр та модуляції, знижується інтенсивність голосу.

Артикуляція. Показником порушення артикуляційної функції $\epsilon$ зменшення обсягу й кількості рухів язика та губ (альтернативні рухи), які при ПнП є порушеними на 100 \%. При оральному обстеженні діагностували знижену тактильну чутливість язика та губ, обмеженість рухів язика, щелепи, губ (альтернативні рухи). Спостерігалася нечітка вимова приголосних звуків, подовжені фонеми, палілалія.

Дихання. Спостерігалося зниження дихальної функції в мовленні, що свідчить про зменшення ємності легень та слабку фонаційну підтримку мовлення. Зменшена кількість слів, які пацієнт вимовляє на один видих.

Просодія. У пацієнтів виражена моногучність та монотонність мовлення, змінені наголоси та інтонація.

Резонанс. Спостерігається зниження функції м’якого піднебіння у вигляді легкої гіперназальності.

Темп. Установлено, що темп мовлення є сповільнений у всіх пацієнтів.

Сумарні результати обстеження зразків мовлення наведені в таблиці 2.

Таблиця 2

\section{Сумарні результати обстеження зразків мовлення}

\begin{tabular}{|l|c|c|}
\hline \multicolumn{1}{|c|}{ Оцінка мовлення } & $\begin{array}{c}\text { Кількість } \\
\text { показників, } \\
\text { відхилених від } \\
\text { норми }\end{array}$ & $\begin{array}{c}\text { Відсоток (\%) } \\
\text { показників, відхилених } \\
\text { від норми }\end{array}$ \\
\hline $\begin{array}{l}\text { Швидкість мовлення (темп мовлення) } \\
\text { повільно (п) } \\
\text { швидко (ш) }\end{array}$ & 5 & 100 \\
\hline Відтермінована ініціація мовлення & - & 0 \\
\hline Подовжені фонеми & 2 & 40 \\
\hline Слабкий голос & 2 & 100 \\
\hline Монотонний & 5 & 100 \\
\hline Моногучний & 5 & 100 \\
\hline Шепітний & 5 & 20 \\
\hline Палілалія & - & 100 \\
\hline Зразок голосу & 1 & 100 \\
\hline Гіпокінетичний & 5 & 40 \\
\hline Стиснений/Дистонічний & 5 & 40 \\
\hline Подовжений & 2 & 2 \\
\hline Атактичний & 2 & 0 \\
\hline
\end{tabular}


У всіх пацієнтів зразок мовлення був гіпокінетичним. У трьох гіпокінетичний зі спастичним компонентом, а у двох інших гіпокінетичний зі спастичним та атактичним компонентами. У всіх пацієнтів спостерігався сповільнений темп мовлення, а у двох - подовження голосних. Відтермінована ініціація мовлення - у 2 пацієнтів. У $100 \%$ пацієнтів мовлення сповільнене, голос - слабкий, монотонний і моногучний, що свідчить про значне порушення просодії. Разом із тим, у всіх пацієнтів відсутній швидкий темп мовлення і шепітний голос. Обстеження пам'яті та когнітивних функцій за короткою шкалою оцінки психічного статусу MMSE показало, що в пацієнтів $\epsilon$ легкий нейрокогнітивний дефіцит (25-26 балів).

Висновки та перспективи подальших наукових розвідок. У результаті проведеного логопедичного обстеження хворих установлено, що дизартрію при ПнП можна віднести до змішаного типу гіпокінетичноспастичної та атактичної дизартрії.

Порівняння порушення мовлення при хворобі ПНП із порушенням мовлення при хворобі Паркінсона дозволило встановити наявність у пацієнтів дизартрії, яка в кожному окремому випадку має свої ознаки, що дозволяють віднести ці дизартрії до різних типів у залежності від ступеня порушення тих чи інших функцій.

При хворобі Паркінсона чітко простежуються прояви гіпокінетичної дизартрії. При ПНП мовлення пацієнтів характеризується моногучністю 3 хриплістю, гіперназальністю, напружено-здавленим голосом, нечіткою артикуляцією й повільним темпом мовлення, що вказує на наявність дизартрії змішаного типу з гіпокінетичними, спастичними та атактичними компонентами.

На даний час не існує єдиного підходу до лікування моторних мовленнєвих розладів. Підходи до лікування залежать від патофізіології (закономірності виникнення, розвитку та завершення хвороби), тяжкості порушень, характеристики специфічних мовленнєвих відхилень, а також від багатьох додаткових факторів, таких, як етіологія, прогноз, неповносправність, соціальне обмеження, оточення, комунікативні потреби тощо.

Наш досвід показує, що концепція підходів до лікування повинна включати щонайменше два напрями: медичний i логопедичний. Медичний ґрунтується на фармакологічній терапії. Під час дослідження ми спостерігали, що завдяки медикаментозному лікуванню покращувалися деякі симптоми, але не всі. Покращення стану пацієнта не завжди означає покращення мовлення.

Однозначно кращі результати досягаються при застосуванні на фоні медикаментозного лікування логопедичної терапії, основною метою якої $\epsilon$ збільшення можливостей комунікації. Для досягнення поставленої мети необхідно проводити логопедичні заняття, скеровані на покращення 
фізіологічної підтримки мовлення, упроваджувати модифікацію мовлення через компенсаторні мовленнєві стратегії, слідкуючи за реакцією хворих під час комунікації.

Лікування мовленнєвих порушень шляхом збільшення фізіологічної підтримки полягає в спробах відновити порушення постави, сили і тонусу артикуляційних м'язів, які лежать в основі розладів мовлення. Поступове збільшення фізіологічної підтримки мовлення сприяє досягненню позитивних результатів на початку лікування.

Максимальна фізіологічна підтримка, зокрема логотерапевтичний метод, повинна бути скерована на відновлення правильного дихання, фонації, резонансу, артикуляції та просодії для покращення ефективності, а головне, - натуральності мовлення. Значною мірою на покращення мовлення впливає мотивація хворих.

у пропонованому методі лікування особливу увагу необхідно звертати на просодію, розвивати потрібний темп, ритм та інтонацію, які несуть у собі важливу синтаксичну інформацію і, по суті, покращують зрозумілість мовлення.

Комунікативно-орієнтовані підходи можуть покращити комунікацію, навіть якщо мовлення само по собі не покращується, тобто їх доцільно використовувати у випадках, коли загальний стан хворого погіршується. Такі підходи включають зміну кількості співрозмовників, дистанції між співрозмовниками, контакт очей для інформування.

Вибір правильної стратегії реабілітації - це завжди пошук оптимального методу спілкування з пацієнтом, який часто вимагає демонстрації і багаторазового повторення логопедичних прийомів. Наприклад, такі прості речі, як повторювання висловлювань, перефразування, вимовляння по буквах довели свою ефективність.

Упровадження й розвиток компенсаторних мовленнєвих стратегій під наглядом логопеда дозволяє підготувати пацієнтів до спілкування в повсякденному житті.

Важливим напрямом терапії мовлення є консультування і підтримка. Завжди необхідно проінформувати пацієнта, чому певні аспекти мовлення не $\epsilon$ нормальні і не можуть навіть бути в нормі. Консультування людей із дегенеративними захворюваннями передбачає постійний творчий підхід і аналіз ефективності застосованих логотерапевтичних методик. Обговорення проблем зміни мовлення із прогресуванням хвороби і можливостей досягнення зрозумілості, комунікативної ефективності 3 урахуванням індивідуальних особливостей пацієнта чи у випадку погіршення стану, дозволить виробити стратегію покращення комунікації, яка буде найефективнішою. 


\section{ЛІТЕРАТУРА}

Оржешковський, В. В., Невмержицька, Н. Н. (2011). Деменції (огляд літератури). Ліки України, 4 (150), 55-59 (Orzheshkovskyi, V. V., Nevmerzhytska, N. N. (2011). Dementia (literature review). M edications of Ukraine, 4 (150), 55-59).

Матвієнко, Ю. О. (2009). Прогресуючий над'ядерний параліч. Медицина світу. Український медичний портал. Режим доступу: http://msvitu.com/archive/2009/march/article-2.php. (Matviienko, Yu. O. (2009). Progressive Supranuclear Palsy. Medicine of the World. Ukrainian medical portal. Retrieved from: http://msvitu.com/archive/2009/march/article-2.php).

Дамулин, И. В., Антоненко, Л. (2005). Особенности нарушений равновесия и ходьбы при болезни паркинсона, прогрессирующем надъядерном параличе $и$ мультисистемной атрофии. Клиническая геронтология, 3, 41-50 (Damulin, Y.V., Antonenko, L. (2005). Features of balance and walking disorders in Parkinson's disease, progressive supranuclear palsy and multisystem atrophy. Clinical gerontology, 3, 41-50).

Ролак, Л. А. (2018). Секреты неврологии. М.: Издательский дом БИНOM (Rolak, L. A. (2018). Secrets of neurology. M .: BINOM ).

Яхно, Н. Н., Захаров, В. В., Локшина, А. Б., Коберская, Н. Н., Мхитарян, Э. А. (2011). Деменции: руководство для врачей. М.: МЕДпресс-информ (Yakhno, N. N., Zakharov, V. V., Lokshyna, A. B., Koberskaia, N. N., M khytarian, E. A. Dementia: a guide for doctors. M.: M EDpress-inform).

Richardson, J., Steele, J., Olszewski, J. (1963). Supranuclear ophthalmoplegia, pseudobulbar palsy, nuchal dystonia and dementia. A clinical report on eight cases of heterogenous system degeneration. Trans Am. Neurol. Assoc., 88, 25-29.

Steele, J., Richardson, J., Olszewski, J. (1964). Progressive supranuclear palsy. A heterogeneous degeneration involving the brain stem, basal ganglia and cerebellum with vertical gaze and pseudobulbar palsy, nuchal dystonia and dementia. Arch. Neurol., 10 (4), 333-359.

Шток, В. Н., Иванова-Смоленская, И. А., Левин, О. С. (2002). Экстрапирамидные расстройства. Руководство по диагностике и лечению. М.: МЕДпресс-информ (Shtok, V. N., Ivanova-Smolenskaia, I. A., Levin, O. S. Extrapyramidal disorders. Diagnostic and treatment guide. M.: M EDpress-inform).

Litvan, I., Agid, Y., Jankovic, J. et al. (1996). Accuracy of clinical criteria for the diagnosis of progressive supranuclear palsy. Neurology, 46, 922-930.

Ульянова, О. В. и др. (2017). Клинический случай прогрессирующего надъядерного паралича. Прикладные информационные аспекты медицины, 17, 193-197 (Ulianova, O. V. et al. (2013). Clinical case of progressive supranuclear palsy. Applied informational aspects of medicine, 17, 193-197).

Lees, A. J. (1987). The Steele-Richardson-Olszewski syndrome (progressive supranuclear palsy). Boston, Butterworth-Heinemann.

Collins, S. J., Ahlskog, J. E., Parisi, J. E., Maraganore, D. M. (1995). Progressive supranuclear palsy: neuropathologically based diagnostic clinical criteria. J. Neurol. Neurosurg Psychiatry, 58, 167-173.

Kluin, K. J. et al. (1993). Perceptual analysis of speech disorders in progressive supranuclear palsy. Neurology, 43, 563-569.

Metter, E. J., Hanson, W. R. (1991). Dysarthria in progressive supranuclear palsy. In Moore C. A., Yorkston K. M., Beukelman D. R. (Eds.), Dysarthria and apraxia of speech: perspectives on management. Baltimore, Paul H. Brookes. 
Golbe, L. I., Davis, P. H., Schoenberg, B. S. et al. (1988). Prevalence and natural history of progressive supranuclear palsy. Neurology, 38, 1031-1034.

Lu, F. L., Duffy, J. R., Maraganore, D. (1992). Neuroclinical and speech characteristics in progressive supranuclear palsy and Parkinson's disease: a retrospective study. Paper presented at the Conference on M otor Speech, Boulder, Colo.

Станецька, Г. М. (2016). Екстрапірамідні розлади мовлення у дорослих. Науковий часопис нПу ім. М.П. Драгоманова. Серія 19. Корекційна педагогіка та спеціальна психологія, 31, 99-102 (Stanetska, H. М. (2016). Extrapyramidal disorders of speech in adults. Scientific journal of NPU named after M. P. Drahomanov. Seriia 19. Correctional Pedagogy and Special Psychology, 31, 99-102).

Федотова, Е. Ю. и др. (2009). Случай прогрессирующего надъядерного паралича с кортикобазальным синдромом. Нервные болезни, 2, 38-43 (Fedotova, E. Yu. et al. (2009). A case of progressive supranuclear palsy with corticobasal syndrome. Nervous diseases, 2, 38-43).

Lebrun, Y., Devreux, F., Rousseau, J. J. (1986). Language and speech in a patient with a clinical diagnosis of progressive supranuclear palsy. Brain Lang, 27, 247-256.

Kluin, K. J. et al. (2001). Neuropathological correlates of dysarthia in progressive supranuclear palsy. Arch Neurology, 58, 265-274.

Pillon, B. at al. (1994). Are explicit memory dosorders of progressive supranuclear palsy related to damage to striatofrontal circuits? Neurology, 44, 1264-1270.

Ситкали, И. В., Раздорская, В. В. (2015). Трудности диагностики прогрессирующего надъядерного паралича. Бюллетень медицинских Интернет-конференций, 5, 273-274 (Sytkaly, I. V., Razdorskaia, V. V. (2015). Difficulties in diagnosing progressive supranuclear palsy. Bulletin of medical internet conferences, 5, 273-274).

Станецька, Г. М. (2018). Комплексний підхід до процесу реабілітації порушення мовлення у дорослих. Тези Всеукраїнської науково-практичної конференції «Формування здоров'язберігаючих компетенцій дітей та молоді: проблеми, розвиток, супровід», 3, 43-45 (Stanetska, H. M. (2018). A comprehensive approach to the process of adult speech impairment. Abstracts of the All-Ukrainian ScientificPractical Conference "Forming the Health of Children and Youth Retaining Competencies: Problems, Development, Support", 3, 43-45).

Шмидт, Р. Ф. (2018). Физиология человека с основами патофизиологи. М.: Лаборатория знаний (Shmidt, R. F. (2018). Human physiology with the basics of pathophysiologists. M.: Laboratory of knowledge).

Дунас, Г. Г. (2008). Методика впровадження комплексної реабілітації в Львівському міжрегіональному центрі сочіально-трудової, професійної та медичної реабілітації інвалідів. Львів: ЗУКЦ (Dunas, H. H. (2008). Methods of implementation of complex rehabilitation at the Lviv Interregional Center for Social, Labor, Professional and M edical Rehabilitation of Persons with Disabilities. Lviv).

Федоришин, Л. В., Станецька, Г. М., Кардош, Н. М., Саноцький, Я. Є. (2010). Рекомендації для пацієнтів із хворобою Паркінсона та їх родичів. Київ: ТЕВА Україна (Fedoryshyn, L. V., Stanetska, H. M., Kardosh, N. M., Sanotskyi, Ya. Ye. Recommendations for patients with Parkinson's disease and their relatives. Kyiv: TEVA UKRAINE).

Смоленцева, И. Г., Левин, О. С., Иллариошкина, С. Н., Амосова, Н. А. (2019). Реабилитация при болезни Паркинсона и синдроме паркинсонизма при других заболеваниях. Клинические рекомендации. М.: МЕДпресс-информ (Smolentseva, I. H., Levin, O. S., Illaryoshkina, S. N., Amosova, N. A. Rehabilitation in Parkinson's disease and Parkinson's syndrome with other diseases. Clinical recommendations. M .: M EDpress-inform). 
Станецька, Г. М., Шеремет, М. К. (2018). Методика діагностики дизартрії при екстрапірамідних розладах у дорослих. Науковий часопис НПу ім. М. П. Драгоманова. Серія 19. Корекційна педагогіка та спеціальна психологія, 36, 94-105 (Stanetska, H. M., Sheremet, M. K. (2018). M ethod of diagnosis of dysarthria in extrapyramidal disorders in adults. Scientific journal of NPU named after M.P. Drahomanov. Seriia 19. Correctional Pedagogy and Special Psychology, 36, 94-105).

Folstein, M. F., Folstein, S. E., M cHugh, P. R. (1975). Miny-M ental State: a practical method for grading the cognitive state of patients for the clinician. J. Psychiatr. Res., 12, 89-198.

\section{PEЗЮME}

Станецкая Галина. Логопедическое исследование нарушения речи при прогрессирующем надъядерном параличе.

В статье описаны особенности нарушения речи у взрослых пациентов, страдающих прогрессирующим надъядерным параличом. B логопедическом перцептивном исследовании приняли участие 5 пациентов, нарушения артикуляции, дыхания, фонации, резонанса, просодии и темпа речи которых оченивались по 25 критериям. Идентифицирована степень нарушения каждого речевого кластера. Установлено, что у пациентов максимально нарушены все функцци языка и гортани, значительно нарушена артикуляция, присутствует легкая гиперназальность и хриплый слабый голос. Пациенты испытывают трудности при необходимости усиления голоса. Функции дыхания и мягкого неба поражены в меньшей степени. Описаны основные характеристики речи и образцы голоса. Обнаружено, что у пациентов наблюдается монотонная замедленная речь со сниженной громкостью, нечеткая артикуляция.

Ключевые слова: нарушение речи, прогрессирующий надъядерный паралич, дизартрия.

\section{SUMMARY}

Stanetska Halyna Logopedic study of speech disorders in progressive supranuclear palsy.

The article describes the disorder peculiarities in speech typical to adult patients who suffer from Progressive Supranuclear Palsy. In speech assessment the 5 patients were involved. We used perceptual speech analysis to evaluate the pattern of speech disturbance. The perceptual speech characteristics were defined across 25 speech dimentions. The article describes the results of detailed perceptual assessment of articulation, respiration, phonation, resonance, prosody and rate. The degree of impairment of each speech cluster was displayed. It has been established that these patients have significantly impaired speech and articulation functions and bad respiratory control for speech, a hoarse weak voice and occasional hypernasality. The patients have shown difficulty with raising vocal volume on command. The most disturbed are all functions of tongue and larynx. Less affected are respiratory and soft palate functions. The main speech characteristics as well as samples of the voice were described. It was found out that patients demonstrated restricted speech prosody, monopitch, monolaudness, reduced speech volume, imprecise articulation, slow rate of speech. Palilalia was evident. Prosody was the most severe affected speech cluster. Perceptual observation revealed that dysarthria was most commonly evident in varying combinations. The presence of hypokinetic dysarthria or mixed dysarthria with hypokinetic, spastic or ataxic components are common. 
The article proves that a speech disorder caused by Progressive Supranuclear Palsy is one of the first features revealed at the beginning of the desease.

The main goal in speech therapy is to raise the effectiveness, efficiency and clarity in the process of communication. The approaches of treatment of speech disorders depend on pathophysiology and specific abnormal speech characteristics as well as multiple additional factors such as etiology, prognosis, disability, communication needs, societal limitations.

The approaches to managment include medical intervention with speech-oriented treatment by modifying respiration, phonation, articulation, resonance, prosody and communication-oriented treatment by alternative and augmentative communication not neglecting counseling and support.

Key words speech impairment, progressive supranuclear palsy, dysarthria.

удк 378.018.8:376-056.264-051

Цимбал-Слатвінська Світлана

Уманський державний педагогічний

університет імені Павла Тичини

ORCID ID 0000-0002-2732-5716

DOI 10.24139/2312-5993/2019.07/026-037

\section{ОСОБЛИВОСТІ ПРОФЕСІЙНОЇ ПІДГОТОВКИ МАЙБУТНІХ ЛОГОПЕДІВ У ЗАКЛАДАХ ВИЩОЇ ОСВІТИ В АСПЕКТІ ПРОФЕСІЙНОї ДІЯЛЬНОСТІ}

У статті розкрито особливості професійної підготовки майбутніх логопедів у закладах вищої освіти в аспекті професійної діяльності. Для їх розкриття визначено сферу діяльності, функції, вимоги до підготовки майбутніх логопедів у закладах вищої освіти. Установлено, що головним обов'язком логопеда є виявлення та надання допомоги дітям із різними аномаліями у психофізичному розвитку. Розкрито специфіку корекційно-розвивальної діяльності майбутнього логопеда, яка полягає в тому, що його мовлення, сфрормована комунікативна компетентність є інструментами корекційного впливу, від ефективності застосування залежать можливості подальшого розвитку та соціалізації дітей і підлітків з вадами мовлення, а також успішність професійнопедагогічного спілкування з ними, їхніми батьками, колегами, адміністрацією.

Ключові слова: особливості, професійна підготовка, майбутні логопеди, закладах вищої освіти, професійна діяльність.

Постановка проблеми. Неухильне зростання кількості дітей, які мають різні форми відхилень у мовленнєвому розвитку, актуалізує потребу у кваліфікованих логопедах. Особливість професії логопеда полягає в тому, що за своєю сутністю вона орієнтована на допомогу іншим людям. Тому вибір саме такої професії передбачає чітко виражену гуманістичну орієнтацію (орієнтацію на людину з їі проблемами). Гуманізація ставлення суспільства до осіб із проблемами в розвитку та інтеграція їх в усі сфери соціального життя вносить суттєві корективи в їхню професійну діяльність (Бессмертная, 2003).

Гуманне ставлення до дітей із мовленнєвими порушеннями може забезпечити тільки особистісно зрілий професіонал, вільний від внутрішньо особистісних конфліктів, відкритий зовнішньому світу, готовий 